\title{
Modulation of the Innate Immune Response by NMDA Receptors Has Neuropathological Consequences
}

\author{
Isaias Glezer, ${ }^{1,2}$ Hakima Zekki, ${ }^{1}$ Cristoforo Scavone, ${ }^{2}$ and Serge Rivest ${ }^{1}$ \\ ${ }^{1}$ Laboratory of Molecular Endocrinology, Centre Hospitalier Université Laval Research Center, and Department of Anatomy and Physiology, Laval \\ University, Québec, Canada G1V 4G2, and 2Department of Pharmacology, Institute of Biomedical Science, University of São Paulo, 05508-900 São Paulo, \\ Brazil
}

The aim of this study was to determine whether glutamate receptors modulate the innate immune response in the brain of $\mathrm{C} 3 \mathrm{H} / \mathrm{HeN}$ and $\mathrm{C} 3 \mathrm{H} / \mathrm{HeJ}$ mice; the latter bear a loss of function in the toll-like receptor (TLR) 4 gene. Mice received an intrastriatal (IS) infusion of lipopolysaccharide (LPS), the exogenous ligand for TLR4, and were killed at several times thereafter. This treatment activated the transcription of a wide variety of genes involved in the control of the innate immune response. MK-801, an antagonist of NMDA glutamate receptor subtype, exacerbated the effects of the endotoxin in the brain of $\mathrm{C} 3 \mathrm{H} / \mathrm{HeN}$ mice but not in TLR4-deficient animals. The ipsilateral side of $\mathrm{C} 3 \mathrm{H} / \mathrm{HeN}$ mice exhibited stronger hybridization signals for the mRNA encoding TLR2, CD14, tumor necrosis factor- $\alpha$, and inhibitory factor $-\kappa \mathrm{B} \alpha$ at various times after the treatment combining MK-801 and LPS. This robust inflammatory response in the brain of $\mathrm{C} 3 \mathrm{H} / \mathrm{HeN}$ mice was not associated with any convincing signs of neurodegeneration or demyelination that was verified via numerous approaches and at time up to 2 weeks after injection. However, animals that received long-term IS infusion of LPS, together with MK-801, exhibited a significant increase in demyelination levels within the ipsilateral side. Our results demonstrate that binding of glutamate to its cognate NMDA receptor modulates LPS-induced innate immune reaction in a TLR4-dependent manner. This acute response may be crucial to eliminate bacterial cell wall components and minimizing tissue injury. However, sustained deregulation of proinflammatory signaling involving NMDA receptors leads to demyelination and is likely to be a mechanism participating in such pathological conditions.

Key words: innate immune response; in situ hybridization histochemistry; inflammation; lipopolysaccharide; proinflammatory cytokines; microglia; macrophages; glutamate; demyelination

\section{Introduction}

Mammalian toll-like receptors (TLRs) are receptors involved in the recognition of pathogen-associated molecular patterns (PAMPs) and also molecules responsible for mounting appropriate responses against microorganisms (Anderson, 2000). Lipopolysaccharide (LPS) is a well characterized inducer of innate immune response recognized by monocytes/macrophages through its binding to membrane CD14 receptors, which transfer LPS to TLR4 via myeloid differentiation protein 2 (Akira et al., 2001). A TLR4 missense mutation was identified in mouse strain $\mathrm{C} 3 \mathrm{H} / \mathrm{HeJ}$ (Poltorak et al., 1998), which is refractory to LPS, and deletion of TLR4 leads to a phenotype that lacks responses against LPS (Beutler, 2000). The stimulation of TLR4 triggers the activity of the nuclear factor $\kappa \mathrm{B}(\mathrm{NF}-\kappa \mathrm{B})$ transduction pathway (Ander-

\footnotetext{
Received Aug. 29, 2003; revised 0ct. 1, 2003; accepted 0ct. 7, 2003.

This work was supported by the Canadian Institutes of Health Research [CIHR; the former Medical Research Council of Canada (MRCC)]. S.R. is an MRCC Scientist and holds a Canadian Research Chair in Neuroimmunology. I.G. is supported by grants from Conselho Nacional de Desenvolvimento Científico e Tecnológico (CNPq) (200842/01-3), Fundação de Amparo à Pesquisa do Estado de São Paulo (00/10679-0), and CIHR. H.Z. is supported by a studentship from the K. M. Hunter/CIHR, and C.S. is a research fellow of CNPq. We thank Dr. A. Israel (Institut Pasteur, Paris, France) for the mouse $I_{\kappa} B \alpha C D N A$, Dr. D. Radzioch (McGill University, Montréal, Canada) for the plasmid containing the mouse TNF- $\alpha$ CDNA, and Dr. K. Pahan (University of Nebraska, Lincoln, NE) for the mouse IL-12p40 cDNA.

Correspondence should be addressed to Dr. Serge Rivest, Laboratory of Molecular Endocrinology, Centre Hospitalier Université Laval Research Center, and Department of Anatomy and Physiology, Laval University, 2705 Boulevard Laurier, Québec, Canada G1V 4G2. E-mail: Serge.Rivest@crchul.ulaval.ca.

Copyright $\odot 2003$ Society for Neuroscience $\quad$ 0270-6474/03/2311094-10\$15.00/0
}

son, 2000). Nuclear translocation of NF- $\kappa$ B activates numerous proinflammatory genes that encode cytokines, chemokines, proteins of the complement system, enzymes, and other molecules essential for pathogen elimination by innate immune response (Ghosh et al., 1998).

Despite the beneficial role of microglial activation in immunemediated host defense, microglial-derived proinflammatory molecules have been associated with neurodegenerative disorders. Activated microglia and astrocytes are found in the brain of Alzheimer's, Parkinson's, and Huntington's disease patients as well as individuals suffering of multiple sclerosis (MS) and amyotrophic lateral sclerosis (Pasinetti, 1998; Gonzales-Scarano and Baltuch, 1999; Nguyen et al., 2002). The serum and CSF of these patients also show elevated levels of immune molecules, such as interleukin (IL)-6, IL-1 $\beta$, and tumor necrosis factor $\alpha$ (TNF- $\alpha$ ) (Pasinetti, 1998; Gonzales-Scarano and Baltuch, 1999; Nguyen et al., 2002). IL- $1 \beta$ and TNF- $\alpha$ are secreted by activated parenchymal microglia and can be potent inducers of cell death in models of neurodegeneration (Pasinetti, 1998; Gonzales-Scarano and Baltuch, 1999; Nguyen et al., 2002).

Glutamate is the major excitatory neurotransmitter in the CNS, and the NMDA subtype of glutamate ionotropic receptors has been implicated in neurodegenerative diseases (Beal, 1995; Simonian and Coyle, 1996). NMDA antagonists attenuate the neuronal cell death induced by many brain insults, making 
NMDA receptor (NMDAR) blockade an attractive approach to prevent neuronal cell death (Beal, 1995). An interplay between glutamatergic transmission and glial response seems to occur because glutamate receptors are localized in glial cells, activated microglia releases molecules that signalize through NMDARs, and glutamate stimulates microglia to release TNF- $\alpha$ (Piani et al., 1992; Noda et al., 1999, 2000; Bezzi and Volterra, 2001; Schipke et al., 2001). Thus, glutamate seems to be a good candidate for mediating the cellular communication between neurons and microglia in both physiological and pathological states. Glutamatergic modulation of microglial cells has important consequences, because these cells are sensitive to minor changes in the microenvironment and they are the major effectors of the cerebral innate immune response that may lead to production of both neurotrophic and neurotoxic molecules (Heese et al., 1998; Stoll and Jander, 1999; Herx et al., 2000; Nguyen et al., 2002).

The aim of this study was, therefore, to determine whether the NMDAR antagonist MK-801 has the ability to alter the inflammatory response in the brain of $\mathrm{C} 3 \mathrm{H} / \mathrm{HeN}$ and $\mathrm{C} 3 \mathrm{H} / \mathrm{HeJ}$ mice in response to an intracerebral bolus of the endotoxin LPS. We also investigated the potential consequences of such response in the cerebral tissue via different approaches.

\section{Materials and Methods Animals}

Adult male C3H/HeN mice (body weight, 25-29 gm; Charles River Canada, St. Constant, Québec, Canada), C3H/HeJ mice (Jax Mice; Jackson Laboratory, Bar Harbor, ME), or Sprague Dawley rats (body weight, $\sim 250$ gm; Charles River Canada) were acclimated to standard laboratory conditions (14/10 hr light/dark cycle; lights on at 6:00 A.M. and off at 8:00 P.M.) with ad libitum access to rodent chow and water. Animal breeding and experiments were conducted according to Canadian Council on Animal Care guidelines, as administered by the Laval University Animal Care Committee.

\section{Experimental protocols}

Acute intraparenchymal injections. Mice receiving intrastriatal (IS) injections were anesthetized with an intraperitoneal injection of avertin $(2,2,2$ tribromoethanol; Sigma-Aldrich, St. Louis, MO) and placed in a stereotaxic apparatus (David Kopf Instruments, Tujunga, CA). The right caudate putamen was reached using a small cannula (33 gauge) at the coordinates $0.0 \mathrm{~mm}$ anteroposterior, $-2.0 \mathrm{~mm}$ lateral, and $-3.0 \mathrm{~mm}$ dorsoventral according to a mouse brain atlas (Paxinos and Franklin, 2001). The animals received an infusion of either sterile pyrogen-free saline $(1 \mu \mathrm{l})$, LPS $(0.5 \mu \mathrm{g}$; from Eschericia coli; serotype O55:B5; Sigma L2880), a mixture of LPS ( $0.5 \mu \mathrm{g})$ and MK-801 maleate ( $1 \mu \mathrm{g}$; Sigma), or MK-801 $(1 \mu \mathrm{g})$ over 2 min by means of a microinjection pump (model A-99; Razel Scientific Instruments, Stanford, CT). Three or four mice were used per group for each time point, for a total number of 96 mice for this experiment.

At different time points, after intraparenchymal injections $(6,24$, and $72 \mathrm{hr}$ and 2 weeks), animals were deeply anesthetized via an intraperitoneal injection of a mixture of ketamine hydrochloride and xylazine and then rapidly perfused transcardially with $0.9 \%$ saline, followed by $4 \%$ paraformaldehyde in $0.1 \mathrm{~m}$ borax buffer, $\mathrm{pH} 9.5$, at $4^{\circ} \mathrm{C}$. Brains were removed rapidly from the skulls, postfixed for $2-4 \mathrm{~d}$, and then placed in a solution containing $10 \%$ sucrose diluted in $4 \%$ paraformaldehydeborax buffer overnight at $4^{\circ} \mathrm{C}$. The frozen brains were mounted on a microtome (Reichert-Jung; Cambridge Instruments Company, Deerfield, IL) and cut into $20 \mu \mathrm{m}$ coronal sections from the olfactory bulb to the end of the medulla. The slices were collected in cold cryoprotectant solution ( 0.05 M sodium phosphate buffer, $\mathrm{pH} 7.3,30 \%$ ethylene glycol, and $20 \%$ glycerol) and stored at $-20^{\circ} \mathrm{C}$.

Long-term intraparenchymal infusions. A chronic indwelling cannula was implanted as described previously (Nadeau and Rivest, 2003). Adult male rats were anesthetized with an intraperitoneal injection of a mixture $(1 \mathrm{ml} / \mathrm{kg}$ body weight $)$ of ketamine hydrochloride $(91 \mathrm{mg} / \mathrm{kg})$ and xyla- zine $(9 \mathrm{mg} / \mathrm{kg})$, and the site of injection was reached stereotaxically (David Kopf Instruments). With the incisor bar placed at $3.3 \mathrm{~mm}$ below the intraneural line (horizontal zero), the coordinates from bregma for the guide cannula (22 gauge; C313G; Plastic One, Roanoke, VA) were 0.0 $\mathrm{mm}$ anteroposterior, $-3.0 \mathrm{~mm}$ lateral, and $-2.8 \mathrm{~mm}$ dorsoventral, according to brain atlas (Paxinos and Watson, 1998). The guide cannula was secured with screws and cranioplastic cement [cranioplastic powder (Plastic One); Dentsply repair material (Dentsply International, York, PA)]. The rats were then housed individually for a $10 \mathrm{~d}$ recuperation period. During the first $3 \mathrm{~d}$ after the surgery, rats received once daily a subcutaneous injection of $8 \mathrm{ml}$ of Ringer's lactate (Abbott Laboratories, Saint-Laurent, Canada) and $50 \mu$ l of ketoprofen (Rhône Mérieux Canada, Victoriaville, Canada). After the recovery period, a mini-osmotic pump (Alzet model 2004; Durect Corporation, Cupertino, CA), connected to an internal cannula (28 gauge; $14 \mathrm{~mm}$ long from the pedestal; C313I; Plastic One) with Intramedic polyethylene tubing (PE-50; inner diameter, $0.58 \mathrm{~mm}$; outer diameter, $0.965 \mathrm{~mm}$; Dow Corning, Midland, MI), was implanted subcutaneously in the interscapular region. The internal cannula was connected to the guide cannula, reaching the dorsoventral coordinate at $-5.0 \mathrm{~mm}$. The pumps (lot 10047-02; pumping rate, $0.29 \mu \mathrm{l} / \mathrm{hr}$ ) were filled with vehicle solution (sterile saline), LPS $(0.0718$ $\mu \mathrm{g} / \mu \mathrm{l}$; yielding $0.5 \mu \mathrm{g} / \mathrm{d}$ ), a mixture of LPS and MK-801 (LPS, $0.0718 \mu \mathrm{g} / \mu \mathrm{l}$; MK-801, $0.1437 \mu \mathrm{g} / \mu \mathrm{l}$; yielding $1 \mu \mathrm{g} / \mathrm{d})$, or MK-801 $(0.1437 \mu \mathrm{g} / \mu \mathrm{l})$ and incubated at $37^{\circ} \mathrm{C}$ in sterile saline solution $48 \mathrm{hr}$ before the implantation in vivo. The animals were killed $72 \mathrm{hr}$ after implantation of the mini-osmotic pumps. Three or five rats per group were used for the intraparenchymal infusion of saline $(n=3)$, LPS $(n=5)$, LPS plus MK-801 $(n=5)$, or MK-801 $(n=3)$. Brain preparation was performed as described above, except for the coronal sections that were cut at $30 \mu \mathrm{m}$ thickness.

\section{cRNA probes and in situ hybridization}

Plasmids were linearized, and the sense and antisense riboprobes were synthesized as described in Table 1 . Radioactive cRNA copies were synthesized by incubation of $250 \mathrm{ng}$ of linearized plasmid in $6 \mathrm{mM} \mathrm{MgCl}_{2}, 40$ mu Tris, pH 7.9, 2 mм spermidine, $10 \mathrm{~mm} \mathrm{NaCl}, 10 \mathrm{~mm}$ DTT, $0.2 \mathrm{~mm}$ ATP/GTP/CTP, $100 \mu \mathrm{Ci}$ of $\alpha-{ }^{35} \mathrm{~S}-\mathrm{UTP}$ (catalog number NEG 039H; DuPont-NEN, Boston, ME), 20 U of RNAsin (Promega, Madison, WI), and $10 \mathrm{U}$ of T7, SP6, or T3 RNA polymerase for $60 \mathrm{~min}$ at $37^{\circ} \mathrm{C}$ (Table 1). Unincorporated nucleotides were removed using the ammonium acetate precipitation method; $100 \mu \mathrm{l}$ of DNase solution ( $1 \mu \mathrm{l}$ DNase, $5 \mu \mathrm{l}$ of 5 $\mathrm{mg} / \mathrm{ml} \mathrm{tRNA}$, and $94 \mu \mathrm{l}$ of $10 \mathrm{~mm}$ Tris/ $10 \mathrm{~mm} \mathrm{MgCl}_{2}$ ) was added, and, 10 min later, a phenol-chloroform extraction was performed. The cRNA was precipitated with $80 \mu \mathrm{l}$ of $5 \mathrm{M}$ ammonium acetate and $500 \mu \mathrm{l}$ of $100 \%$ ethanol for $20 \mathrm{~min}$ on dry ice. The pellet was dried and ressuspended in $50 \mu \mathrm{l}$ of $10 \mathrm{~mm}$ Tris/1 mm EDTA. A concentration of $10^{7} \mathrm{cpm}$ probe was mixed into $1 \mathrm{ml}$ of hybridization solution $(500 \mu \mathrm{l}$ formamide, $60 \mu \mathrm{l}$ of 5 $\mathrm{M} \mathrm{NaCl}, 10 \mu \mathrm{l}$ of 1 м Tris, pH 8.0, $2 \mu \mathrm{l}$ of $0.5 \mathrm{M}$ EDTA, pH 8.0, $50 \mu \mathrm{l}$ of $20 \times$ Dehart's solution, $200 \mu \mathrm{l}$ of $50 \%$ dextran sulfate, $50 \mu \mathrm{l}$ of $10 \mathrm{mg} / \mathrm{ml}$ tRNA, $10 \mu \mathrm{l}$ of $1 \mathrm{~m}$ DTT, and $118 \mu \mathrm{l}$ of DEPC water minus volume of probe used). This solution was mixed and heated for $10 \mathrm{~min}$ at $65^{\circ} \mathrm{C}$ before being spotted on slides.

Hybridization histochemical localization of TLR2, inhibitory factor $\kappa \mathrm{B} \alpha(\mathrm{I} \kappa \mathrm{B} \alpha)$, TNF- $\alpha$, cluster of differentiation 14 (CD14), inducible nitric oxide synthase (iNOS), IL-12 p40, interferon (IFN)- $\gamma$, and NMDAR1 mRNA was performed on every 12th section of the entire rostrocaudal extent of each brain, as described previously (Laflamme et al., 1999). The sections were exposed at $4^{\circ} \mathrm{C}$ to $\mathrm{x}$-ray films (Biomax; Kodak, Rochester, NY) for 1-3 d. The slides were thereafter defatted in xylene, dipped in NTB-2 nuclear emulsion (diluted 1:1 with distilled water; Kodak), exposed for $15 \mathrm{~d}$ (iNOS, IL-12, p40, and IFN- $\gamma$ transcripts), $13 \mathrm{~d}$ (TLR2 and CD14 transcripts), $10 \mathrm{~d}$ (TNF- $\alpha$ ), $7 \mathrm{~d}$ (I $\kappa \mathrm{B} \alpha$ transcript), or $4 \mathrm{~d}$ (NMDAR1 transcript). The slides were then developed in D19 developer (Kodak) for $3.5 \mathrm{~min}$ at $14-16^{\circ} \mathrm{C}$, washed for $15 \mathrm{sec}$ in water, and fixed in rapid fixer (Kodak) for $5 \mathrm{~min}$. Tissues were thereafter rinsed in running distilled water for $1 \mathrm{hr}$, counterstained with thionin $(0.25 \%)$, dehydrated through graded concentrations of alcohol, cleared in xylene, and coverslipped with distrene plasticizer xylene (DPX) mounting media (Electron Microscopy Science, Washington, PA). 
Table 1. Plasmids and enzymes used for the synthesis of the cRNA probes

\begin{tabular}{|c|c|c|c|c|c|}
\hline Plasmid & Vector & Length (bp) & $\begin{array}{l}\text { Enzymes used for } \\
\text { the sense probe }\end{array}$ & $\begin{array}{l}\text { Enzymes used for the } \\
\text { antisense probe }\end{array}$ & Source \\
\hline Mouse TLR2 & PCR-blunt II-topo & 2278 (almost full) & Spe/T7 & EcoRV/Sp6 & Cloned by $P C R^{a}$ \\
\hline Mouse $I \kappa \mathrm{B} \alpha$ & Bluescript SK II+ & 1114 (full) & HindlII/T3 & BamHI/T7 & Dr. A. Israël (Institut Pasteur, Paris, France) \\
\hline Mouse TNF- $\alpha$ & Bluescript SK II+ & $\begin{array}{l}1300 \text { (full + a } 593 \text { bp } \\
\text { non-coding part) }\end{array}$ & $\mathrm{BamHI} / \mathrm{T7}$ & Pstl/T3 & $\begin{array}{l}\text { Subcloned from a PUc19 plasmid provided by Dr. M. Oliver } \\
\text { (Laval University, Québec, Canada) }\end{array}$ \\
\hline Mouse CD14 & $\mathrm{pRc} / \mathrm{CMV}(5.4 \mathrm{~kb})$ & 1500 & HindllI/SP6 & Apal/T7 & Dr. Regine Landmann (University Hospital, Basel, Switzerland) \\
\hline Mouse iNOS & Bluescript SK II+ & 817 & EcoRI/T7 & $\mathrm{Kpnl} / \mathrm{T3}$ & Subcloned from a Puc19 plasmid provided by Dr. M. Oliver \\
\hline Mouse NMDAR1 & pCMV-sport 6 & 3300 & Hindll/Sp6 & Sall/T7 & American Type Culture Collection (Manassas, VA) \\
\hline Mouse IL-12 p40 & pCL-Neo (5.474 kb) & 1050 & Notl/T7 & Xhol/T3 & Dr. K. Pahan (Nebraska Medical Center University, Lincoln, NE) \\
\hline Mouse IFN- $\gamma$ & pGEMEX & 550 & EcoRI/SP6 & HindllI/T3 & Dr. I. Campbell (The Scripps Research Institute, La Jolla, CA) \\
\hline
\end{tabular}

${ }^{a}$ The DNA fragment of $2.278 \mathrm{~kb}$ corresponding to the almost complete coding sequence (2.355 kb) of the reported mouse TLR2 mRNA (nucleotides 307-2661; Genbank accession number AF185284) was amplified by PCR from a CDNA macrophage B10R cell line library using a pair of 23 bp oligonucleotide primers complementary to nucleotides 323-345 (5' -GGCTCTTCTGGATCTTGGTGGCC-3') and 2579-2601 (5' -GGGCCACTCCAGGTAGGTCTTGG-3').

Detection of neuronal cell death, demyelination, and histological analysis

The presence of neuronal cell death was investigated with the FluoroJade B (FJB) method. Briefly, every 12th section of the whole rostrocaudal extent of each brain was mounted onto poly-L-lysine-coated slides, dried under vacuum for $2 \mathrm{hr}$, dehydrated through graded concentrations of alcohol (50, 70, and 100\%; $1 \mathrm{~min}$ ), rehydrated through graded concentrations of alcohol (100, 70, and 50\%; $1 \mathrm{~min})$, and rinsed for $1 \mathrm{~min}$ in distilled water. Then, the sections were dipped and shacked in potassium permanganate solution $(0.06 \%)$ for $10 \mathrm{~min}$ and rinsed for $1 \mathrm{~min}$ in distilled water. Slides were next dipped and shacked into a solution containing a mixture of $0.0004 \%$ FJB (Histochem, Jefferson, AR) plus $0.1 \%$ acetic acid (Sigma-Aldrich) plus $0.0002 \%$ 4',6'-diamidino-2phenylindole (Molecular Probes, Eugene, OR) for $20 \mathrm{~min}$. The slides were thereafter rinsed three times in distilled water ( $1 \mathrm{~min}$ each), dried, dipped in xylene three times ( 2 min each), and coverslipped with DPX.

Demyelination was determined via Luxol Fast Blue (LFB) staining. The brain sections mounted onto poly-L-lysine-coated slides were dehydrated through graded concentrations of alcohol (50, 70, and 95\%; $1 \mathrm{~min}$ each) and incubated at $60^{\circ} \mathrm{C}$ for $6 \mathrm{hr}$ in LFB solution [ $1 \%$ Solvent Blue 38 (Sigma) in $95 \%$ ethanol and $0.5 \%$ acetic acid]. The sections were then rinsed in $95 \%$ ethanol ( $1 \mathrm{~min}), 0.05 \%$ lithium carbonate (1-5 min; Sigma), and $70 \%$ alcohol (two dips). Thereafter, the slides were stained in $1 \%$ eosine Y solution (EM Diagnostic System, Gibbstown, NJ) for $30 \mathrm{sec}$, rinsed in water, incubated in $0.25 \%$ cresyl violet (Sigma) for $30 \mathrm{sec}$, rinsed in water, dehydrated through graded concentrations of alcohol $(50,70,95$, and $100 \%$; 1 min each), cleared in xylene for 1 min (two times), and coverslipped with DPX.

Nissl stain was used as a general index of cellular morphology that may be altered in response to the different treatments.

\section{Quantitative analysis}

Quantitative analyses were performed as described previously (Nadeau and Rivest, 2003). Hybridization signals were quantified on $\mathrm{x}$-ray films (Biomax). Briefly, transmittance values (optical density) of the hybridization signal were measured under a Northern Light Desktop Illuminator (Imaging Research) using a Sony Camera Video System attached to a Micro-Nikkor $55 \mathrm{~mm}$-Vivitar extension tube set coupled with a computer and NIH Image software version 1.59/ppc [written by W. Rasband (National Institutes of Health, Bethesda, MD) and available from the internet by anonymous ftp from http://rsb.info.nih.gov/nih-image/ download.html]. OD values for each pixel were calculated using a known standard of intensity and distance measurements from a logarithmic specter adapted from Bioimage Visage 110s (Millipore, Ann Arbor, MI). The entire hemisphere ipsilateral to the injection site was digitized and subjected to densitometric analysis, yielding measurements of mean density per area. The OD of each hemisphere was then corrected for the average background signal by subtracting the OD of area without positive signal located in the contralateral side. Four different brain sections at the level of caudate putamen were used for each animal.

The dorsal basal ganglia and hippocampus were selected for the semiquantification of NMDAR1 mRNA. These structures exhibited high constitutive NMDAR1 expression levels and strong transcriptional activa- tion of immune-related genes in response to intracerebral LPS/MK-801 administration. Measurements were performed in $10 \mathrm{C} 3 \mathrm{H} / \mathrm{HeN}$ and 10 $\mathrm{C} 3 \mathrm{H} / \mathrm{HeJ}$ mice, and data are reported as mean OD values ( \pm SEM).

Demyelination was evaluated on digitalized LFB-stained sections within the corpus callosum and caudoputamen as described previously (Nadeau and Rivest, 2003). The rationale to measure LFB staining (index of myelinated fibers) in these regions is based on the pattern of the inflammatory wave that diffused across the dorsal basal ganglia and corpus collosum in response to cerebral infusions. Briefly, OD of corpus callosum and caudato putamen was measured using the NIH Image software, and values of the contralateral side were subtracted from those of the ipsilateral side of four different rostrocaudal levels and expressed as absolute values (mean \pm SEM).

The statistical analysis was performed by a one- or two-way ANOVA, followed by a Bonferroni/Dunn test procedure as post hoc comparisons or Student's $t$ test for NMDAR1 subunit mRNA levels.

\section{Results \\ LPS-induced expression of TLR2 and CD14 is modulated by MK-801 in a TLR4-dependent manner}

Figure 1 depicts representative hybridization signals in the brain of mice treated with saline, LPS, LPS/MK-801, or MK-801 alone. As expected, implantation of the cannula and the stress of infusion caused a low expression of TLR2 mRNA. Such a localized pattern of positive TLR2-expressing cells was found in the brain of both saline- and MK-801-infused mice (Fig. 1). This low signal contrasts with the intense and widespread transcriptional activation of TLR2 ipsilateral to the side of LPS infusion (Fig. 1Ab, LPS). MK-801 exacerbated the effects of endotoxin injected directly within the basal ganglia. At $24 \mathrm{hr}$, the signal was more intense in the brain of mice treated with the NMDAR antagonist and endotoxin (Fig. 1Ac). Semiquantitative analyses performed on $\mathrm{x}$-ray films revealed a significant difference between the LPSand LPS/MK-801-treated groups (Fig. 1C).

This amplification by MK-801 was essentially abolished in $\mathrm{C} 3 \mathrm{H} / \mathrm{HeJ}$ mice, because these mice were much less sensitive to either LPS alone or combined with the NMDAR antagonist (Fig. $1 \mathrm{~B})$. It is interesting to note that despite the lack of functional TLR4, a single intracerebral bolus of LPS was able to increase TLR2 expression in regions ipsilateral to the injection site. However, the signal was, to a great extent, lower in $\mathrm{C} 3 \mathrm{H} / \mathrm{HeJ}$ mice than in their wild-type controls, and MK-801 remained without significant effect in TLR4-mutant mice (Fig. $1 B, C$ ). These data indicate that the ability of glutamate and NMDARs to modulate the innate immune response in the brain is dependent on the prior binding of LPS to its receptor TLR4.

The same phenomenon took place for the gene encoding CD14 (Fig. 2). The endotoxin caused a profound increase in the transcriptional activation of the gene encoding LPS receptor in 


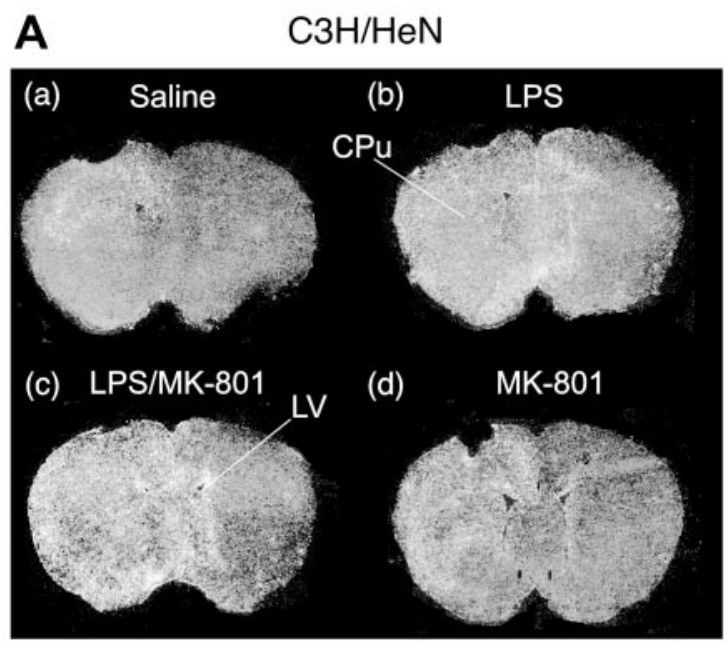

\section{B $\quad \mathrm{C} 3 \mathrm{H} / \mathrm{HeJ}$}

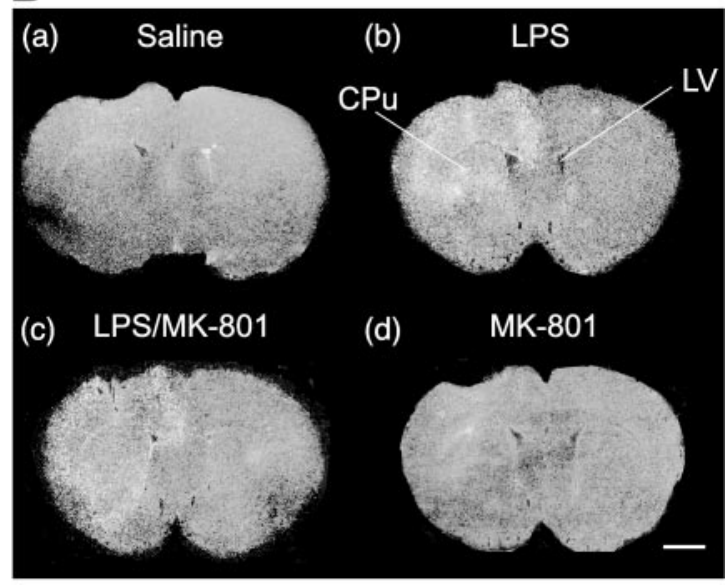

C

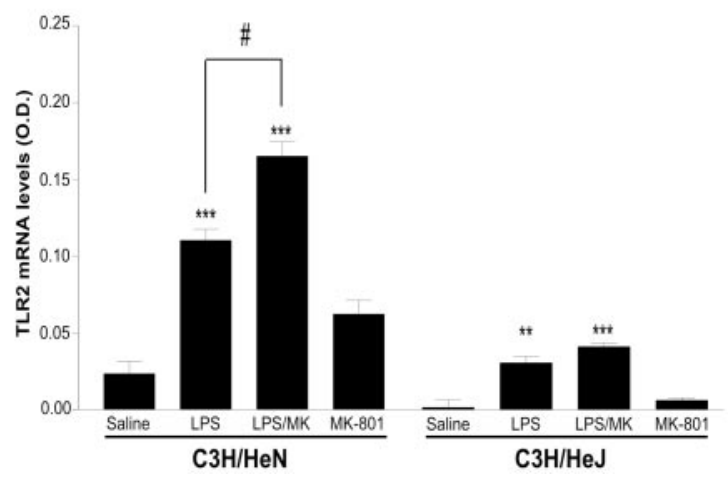

Figure 1. TLR2 $m R N A$ expression in the brain of $\mathrm{C} 3 \mathrm{H} / \mathrm{HeN}$ and $\mathrm{C} 3 \mathrm{H} / \mathrm{HeJ}$ mice after an intraparenchymal bolus of saline, LPS, or the antagonist of the NMDAR MK-801. A, Representative hybridization signals in emulsion-dipped coronal sections $(20 \mu \mathrm{m})$ taken from $\mathrm{C} 3 \mathrm{H} / \mathrm{HeN}$ mice that received only saline solution $(a), \operatorname{LPS}(b ; 0.5 \mu \mathrm{g})$, a mixture containing LPS $(0.5 \mu \mathrm{g})$ and MK-801 ( $c ; 1 \mu \mathrm{g}$, LPS/MK-801), or MK-801 (d; $1 \mu \mathrm{g})$ in the dorsal basal ganglia. $B$, Emulsiondipped coronal sections of $\mathrm{C} 3 \mathrm{H} / \mathrm{HeJ}$ mice, which bear a loss of function in the TLR4, killed $24 \mathrm{hr}$ after a single bolus of saline solution ( $a$ ), LPS (b), LPS combined with MK-801 (c), and MK-801 (d). C, Semiquantitative analysis of TLR2 mRNA levels (OD) in the ipsilateral side of $\mathrm{C} 3 \mathrm{H} / \mathrm{HeN}$ and $\mathrm{C} 3 \mathrm{H} / \mathrm{HeJ}$ mice $24 \mathrm{hr}$ after the intracerebral insults. Please note the robust hybridization signal across the ipsilateral side of mice that received LPS combined with the antagonist of the NMDARs. Results represent means \pm SEM of three to four mice per group. Statistical analysis was performed by using a two-way ANOVA, followed by a Bonferroni's multiple comparison test. ${ }^{* *}$ Significantly different $(p<0.01)$ from saline-injected group; ${ }^{* * *}$ significantly different $(p<0.001$ ) from saline-injected group; \#significantly different $(p<0.05)$. For more details, see Materials and Methods. CPu, Caudate putamen; LV, lateral ventricle. Scale bar, $1250 \mu \mathrm{m}$. the ipsilateral side of mice killed $6 \mathrm{hr}$ after the single intraparenchymal infusion. The cells lining the leptomeninges and few blood vessels exhibited a strong hybridization signal for CD14 transcript $6 \mathrm{hr}$ after the cerebral injection with LPS alone or combined with MK-801 (Fig. 2b,c). As for TLR2, the expression wave across the brain parenchyma increased in intensity $24 \mathrm{hr}$ after the treatment combining LPS with the antagonist of the NMDAR (Fig. $2 k$ ). This effect of MK-801 persisted up to $72 \mathrm{hr}$ after injection, but the differences in the hybridization signal were not as marked as those found at $24 \mathrm{hr}$ (Fig. 2j,k,rs). Once again, C3H/ $\mathrm{HeJ}$ mice were relatively resistant to the treatments, but the endotoxin was capable of causing an increase in CD14 gene expression in a localized area ipsilateral to the injection site at $6 \mathrm{hr}$ (Fig. $2 f, g)$. The signal largely decreased in the brain of these mice $24 \mathrm{hr}$ after the intracerebral administration of the endotoxin that was combined or not with MK-801 (Fig. 2n,o). Seventy-two hours after the different treatments, very few positive CD14-expressing cells were found in the CNS of $\mathrm{CH} 3 / \mathrm{HeJ}$ mice (Fig. $2 v, w$ ).

\section{TLR4-dependent induction of proinflammatory signaling and gene transcription}

The next series of assays evaluated whether expression of receptors involved in the innate immune response is associated with an increase in NF- $\kappa \mathrm{B}$ signaling and transcriptional activation of genes encoding molecules involved in neurodegenerative disorders. The wave of TNF- $\alpha$-expressing cells was characterized by strong signals at the edges of the inflammatory area restricted to the ipsilateral side $6 \mathrm{hr}$ after LPS or LPS plus MK-801 infusions (Fig. $3 b, c)$. At this time point, $\mathrm{C} 3 \mathrm{H} / \mathrm{HeJ}$ mice were relatively resistant to the endotoxin, although scattered positive TNF- $\alpha$ cells were detected in the infused region (Fig. $3 f, g$ ). Surprisingly, a robust hybridization signal was found in the brain of both mouse strains $24 \mathrm{hr}$ after the single IS bolus of LPS (Fig. 3j,k,n,o). The message vanished quickly in the brain of $\mathrm{C} 3 \mathrm{H} / \mathrm{HeJ}$ mice (Fig. $3 v, w)$, but remained positive and scattered across the injection site of $\mathrm{C} 3 \mathrm{H} / \mathrm{HeN}$ animals at $72 \mathrm{hr}$ (Fig. $3 r, s$ ). The endotoxin is, therefore, able to trigger transcriptional activation of TNF- $\alpha$ in a very transient manner without a functional TLR4. Here, the effects of the antagonist of the NMDARs were not as convincing as for the other transcripts. However, TNF- $\alpha$ mRNA levels were, in general, higher in the CNS of most $\mathrm{C} 3 \mathrm{H} / \mathrm{HeN}$ mice treated with LPS and MK-801 and killed $6 \mathrm{hr}$ afterward (Fig. $3 c$ ).

De novo induction of $\mathrm{I} \kappa \mathrm{B} \alpha \mathrm{mRNA}$ is a reliable index of NF- $\kappa$ $B$ activity, and a strong hybridization was detected in the CNS of $\mathrm{C} 3 \mathrm{H} / \mathrm{HeN}$ mice (Fig. $4 A$ ). Indeed, IS infusion of LPS caused a diffuse pattern of positive cells across the brain parenchyma. The signal was already strong at $6 \mathrm{hr}$ and remained positive up to $72 \mathrm{hr}$ after LPS infusion (data not shown). The combined administration of LPS with the inhibitor of the NMDARs provoked a strong and widespread expression of $\mathrm{I} \kappa \mathrm{B} \alpha$ mRNA in cells lining the ventricle ependyma, leptomeninges, blood vessels, and across the brain parenchyma ipsilateral to the injection site. The hybridization signal was clearly higher in the cerebral tissues of $\mathrm{C} 3 \mathrm{H} / \mathrm{HeN}$ mice treated with LPS and MK-801 than those of mice challenged only with the endotoxin and killed $6 \mathrm{hr}$ afterward (Fig. $4 A b, c$ ). It is interesting to note that mice killed $24 \mathrm{hr}$ after the various treatments still exhibited a similar pattern of I $\kappa \mathrm{B} \alpha$-expressing cells, but the message returned to a comparable level at $72 \mathrm{hr}$ (data not shown). Although individual variations were observed among animals of that group, MK- 801 was able to increase $\mathrm{I} \kappa \mathrm{B} \alpha$ expression in response to LPS at 6 and $24 \mathrm{hr}$. I $\kappa \mathrm{B} \alpha$ mRNA levels were barely detectable in the brain of $\mathrm{C} 3 \mathrm{H} / \mathrm{HeJ}$ mice, which indicates 
that exacerbation of the proinflammatory signaling by MK-801 depends on a functional TLR4.

Unlike the other transcripts, no positive signal was found for the gene encoding iNOS in the brain of $\mathrm{C} 3 \mathrm{H} / \mathrm{HeJ}$ mice in response to the endotoxin injected either alone or together with MK-801 (Fig. 4B). In $\mathrm{C} 3 \mathrm{H} / \mathrm{HeN}$ mice, the message significantly increased over the background level $6 \mathrm{hr}$ after the intracerebral infusion of LPS alone or combined with MK-801 (Fig. $4 B j, k)$. At $24 \mathrm{hr}$, numerous clusters of iNOS-expressing cells were detected in the region infused with endotoxin, and the antagonist of the NMDARs failed to modulate the pattern of iNOS expression that was nonuniform and restricted to isolated clusters of positive cells (data not shown). The signal returned to background levels $72 \mathrm{hr}$ after the IS infusion with the bacterial cell wall component combined or not with MK-801 (data not shown).

\section{NMDAR1 subunit expression in the} brain of $\mathrm{C} 3 \mathrm{H} / \mathrm{HeN}$ and $\mathrm{C} 3 \mathrm{H} / \mathrm{HeJ}$ mice To verify whether the NMDA antagonist failed to modulate LPS-induced immune response in $\mathrm{C} 3 \mathrm{H} / \mathrm{HeJ}$ mice because of a major difference in receptor expression, NMDAR1 subunit mRNA was measured via in situ hybridization histochemistry. As shown in Figure 5, the pattern and intensity of NMDAR1 gene expression were similar in the brain of both mouse strains. The distribution of the gene encoding this critical NMDAR was also similar to that already described in other studies (Laurie and Seeburg, 1994). Semiquantitative analyses were performed in caudate putamen and hippocampus because of the high expression levels and welldefined pattern of the receptor transcript in these structures. $\mathrm{C} 3 \mathrm{H} / \mathrm{HeN}$ and $\mathrm{C} 3 \mathrm{H} /$ $\mathrm{HeJ}$ mice exhibited similar NMDAR1 mRNA levels in different regions of the brain (Fig. 5C).

\section{Integrity of the neuronal elements}

The consequences of altering the inflammatory response by MK801 and TLR4 on the cerebral tissue were determined via two different approaches. FJB is a polyanionic fluorescein derivative that has been shown to be a sensitive and reliable marker for histochemical localization of neuronal degeneration (Schmued et al., 1997). Brain sections of animals with bilateral adrenalectomy were used as positive control, because a subpopulation of cells within the dentate gyrus granular layer are known to undergo neuronal cell death under this treatment. These neurons displayed strong and selective fluorescent FJB signals in the sections of a rat killed $6 \mathrm{~d}$ after being adrenalectomized (Fig. $6 \mathrm{Aa}$ ). Such positive cells were never observed in the brain of LPS- or LPS plus MK-801-treated C3H/HeN mice 24 or $72 \mathrm{hr}$ after infusions (Fig. $6 A b-g)$, except for the neurons adjacent to the cannula track. FJB

\section{CD14 mRNA}
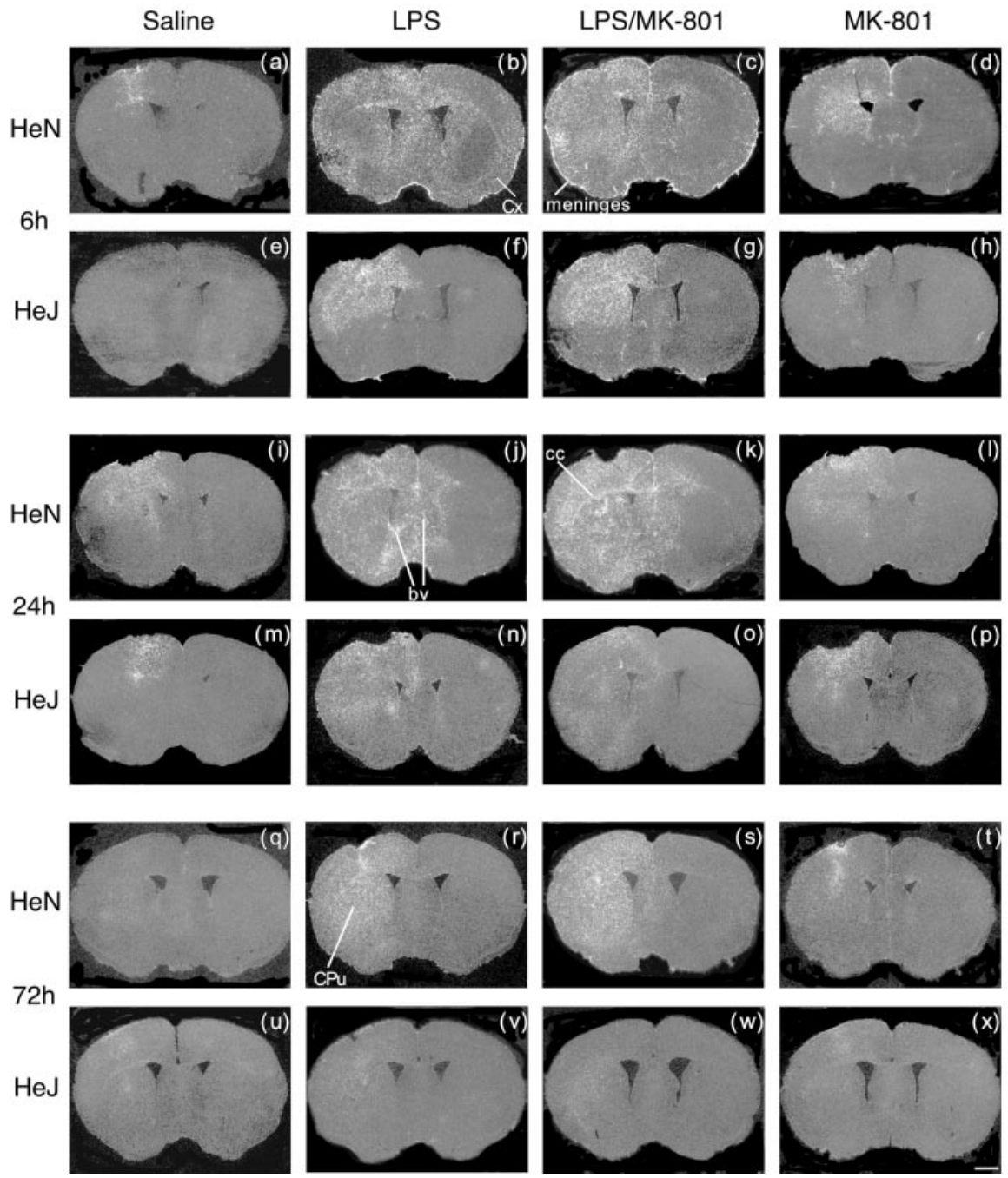

Figure 2. Time-related expression of CD14 mRNA in the brain of $\mathrm{C} 3 \mathrm{H} / \mathrm{HeN}$ and $\mathrm{C} 3 \mathrm{H} / \mathrm{HeJ}$ mice after a single intraparenchymal CRNA probe and dipped into nuclear emulsion milk. These images are representative examples of the expression pattern of CD14 transcript $6 \mathrm{hr}(a-h), 24 \mathrm{hr}(i-p)$, and $72 \mathrm{hr}(q-x)$ after the infusion with saline, LPS, LPS plus MK-801, or MK-801 alone. Please effect was impaired in HeJ mice, the endotoxin was still capable of causing a significant increase in CD14 transcription in the brain of this strain $(f, g)$. bv, Blood vessels; cc, corpus callosum; CPu, caudate putamen; Cx, cortex. Scale bar, $1000 \mu \mathrm{m}$. neurons along the tract were found in all animals, including those infused only with vehicle solutions (Fig. 6Ab). Few capillaries of LPS-treated mice contained small and scattered positive cells, which are likely to be infiltrating cells (Fig. 6Ad-f, insets). Neurons remained negative for the fluorochrome FJB up to 2 weeks after the different treatments in both $\mathrm{C} 3 \mathrm{H} / \mathrm{HeN}$ and $\mathrm{C} 3 \mathrm{H} / \mathrm{HeJ}$ mice.

Nissl stain was also used to evaluate the morphology and histological integrity of the cerebral tissues. Figure $6 B$ shows examples of brain sections taken from saline-, LPS-, or LPS plus MK801-infused mice, and no convincing changes were observed 72 hr after the different treatments (Fig. $6 B a-c$ ). The sections remained intact, and ipsilateral sides were similar to the contralateral areas at 2 weeks after LPS infusion in both mouse strains (Fig. $6 B d-f)$. 


\section{TNF $\alpha$ mRNA}
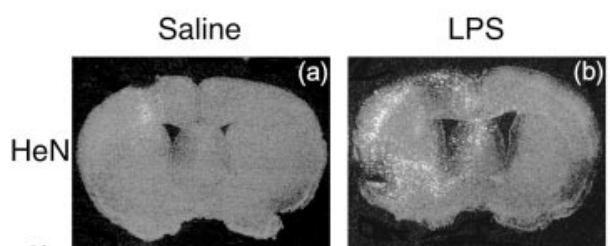

$6 \mathrm{~h}$
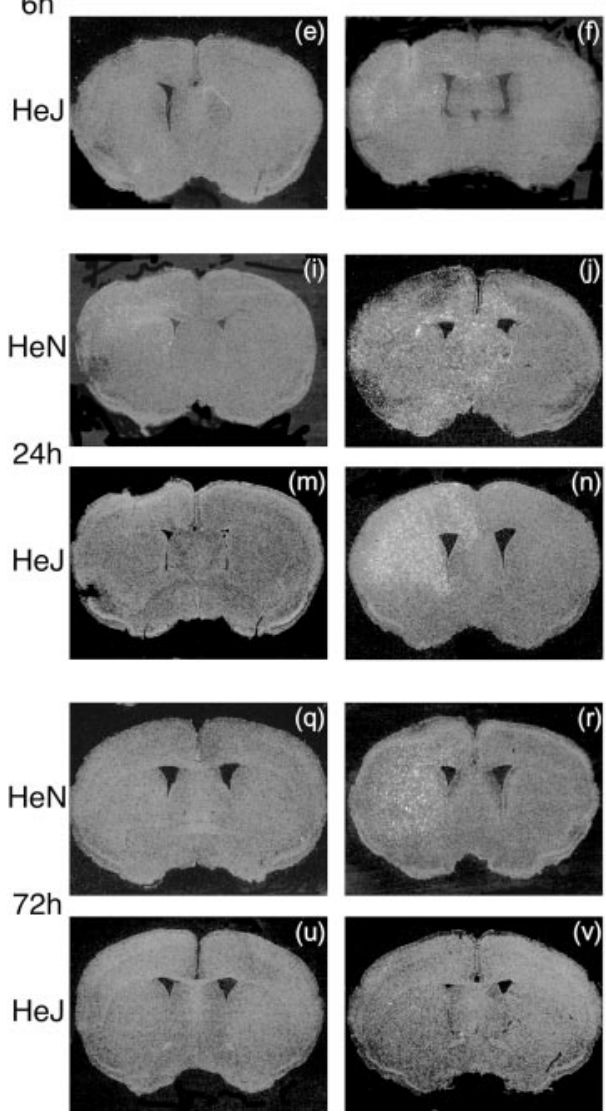
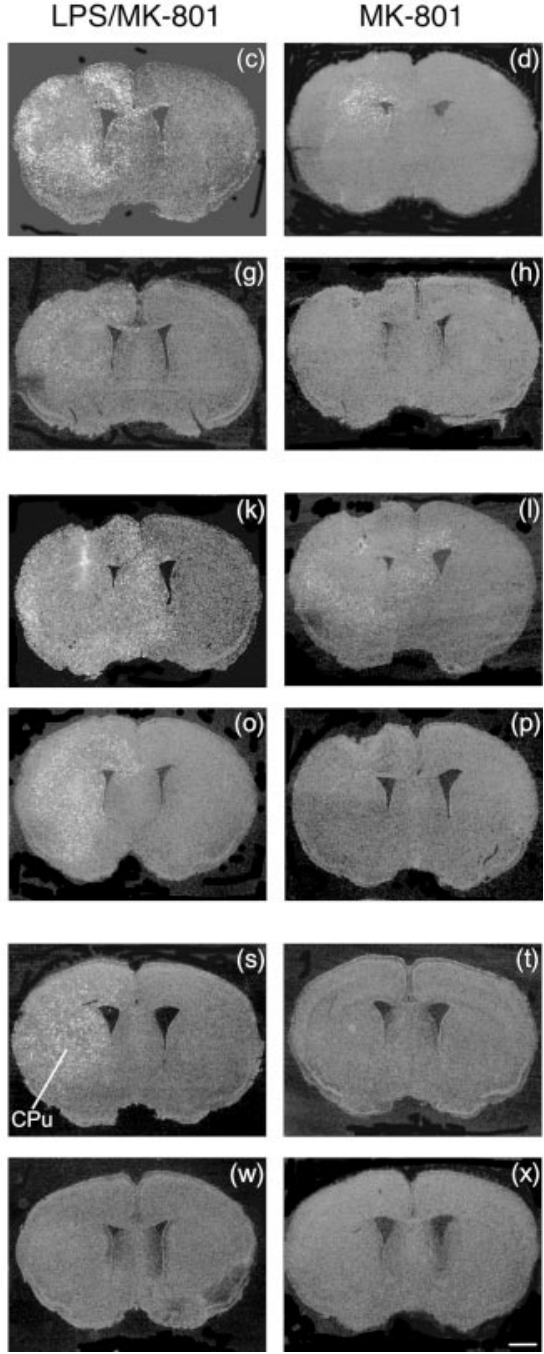
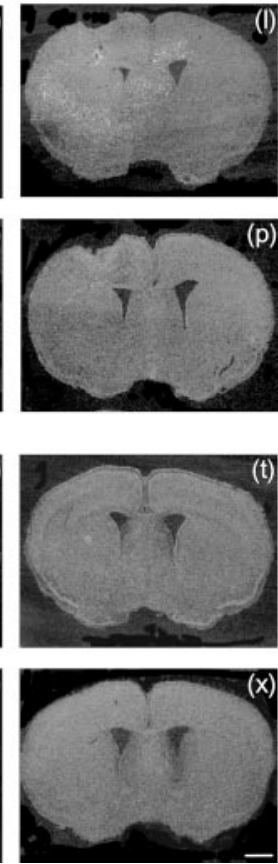

Figure 3. Expression wave of the proinflammatory cytokine TNF- $\alpha$ in response to intrastriatal infusion of LPS and MK-801. Representative nuclear emulsion dipped coronal sections depicting the effects of LPS and MK-801 on TNF $\alpha$ gene expression in $\mathrm{C} 3 \mathrm{H} / \mathrm{HeN}$ and $\mathrm{C} 3 \mathrm{H} / \mathrm{HeJ}$ mouse brains at $6 \mathrm{hr}(a-h), 24 \mathrm{hr}(i-p)$, and $72 \mathrm{hr}(q-x)$ after injections. Please note the rapid expression of the gene encoding the cytokine in the brain of $\mathrm{C} 3 \mathrm{H} / \mathrm{HeN}$ mice after coadministration of LPS and MK-801. The endotoxin also stimulated TNF- $\alpha$ gene expression in the CNS of C3H/HeJ mice, especially at $24 \mathrm{hr}(n, 0)$. CPu, Caudate putamen. Scale bar, $1000 \mu \mathrm{m}$.

\section{Genes involved in the transfer from the innate to} adaptive immunity

The gene encoding TLR2 was still expressed in the brains of $\mathrm{C} 3 \mathrm{H} /$ HeN mice 2 weeks after the single bolus of LPS (Fig. $7 a$ ) but not in those of $\mathrm{C} 3 \mathrm{H} / \mathrm{HeJ}$ mice (Fig. $7 b$ ). Few positive and small scattered $\mathrm{I} \kappa \mathrm{B} \alpha$ - and TNF- $\alpha$-expressing cells were also found, but the cerebral tissues of all groups remained without detectable signal for both IL-12 and IFN- $\gamma$ transcripts. Positive controls for these two genes were hybridized in the brains of mice infected with herpes simplex virus type 2 , which causes a profound neurodegeneration associated with innate and adaptive immune responses (Boivin et al., 2002).

\section{Brain damage caused by a long-term infusion}

To verify the relevance of innate immune response modulated by glutamate to brain physiopathology, an experimental protocol was designed to expose the cerebral tissue to long-term stimulation. Figure 8 depicts LFB-stained sections from animals treated with saline, LPS, LPS combined with MK801, or MK-801 alone during 72 hr. Animals that received combined treatment of LPS plus MK-801 exhibited a striking degree of demyelination compared with the other groups, which was confirmed by semiquantitative analysis of differential OD with the contralateral side (Fig. $8 A, B$ ). LPS infusion for a period of $3 \mathrm{~d}$ was also able to cause demyelination, but differential OD failed to reach statistical significance because of the high degree of variability among animals of this group (Fig. $8 A, B)$. It is possible that variable diffusions throughout the brain parenchyma contribute to different degrees of demyelination between animals and dorsoventralrostrocaudal levels. However, demyelination was clear in all animals that received the double treatment, which was not the case in the cerebral tissue of rats that were infused only with the endotoxin. Demyelination was apparently not associated with neuronal cell death, because no positive FJB neurons were found in the brain of chronically treated rats. This pattern of demyelination was never observed in the brain of $\mathrm{C} 3 \mathrm{H} / \mathrm{HeN}$ or $\mathrm{C} 3 \mathrm{H} / \mathrm{HeJ}$ mice that received an acute bolus with the different solutions (data not shown).

\section{Discussion}

Innate immune response is crucial for protecting the brain and maintaining its integrity against invading microorganisms. Characterization of TLRs highlighted the existence of receptors for recognizing specific PAMPs and mounting an organized response to eliminate pathogens. TLR4 is believed to be an essential receptor for proper response to LPS but not other PAMPs (Anderson, 2000). Unexpectedly, TLR4 seems to be a receptor involved in the responses of myeloid cells to Taxol and some heat shock proteins, implying that TLR4 can also be a detector of "danger signals” (Underhill and Ozinsky, 2002; Wallin et al., 2002). TLR4 mRNA is expressed at low levels in the brain under basal conditions, and downregulation takes place in response to LPS injected either systemically or centrally (Laflamme and Rivest, 2001; Nadeau and Rivest, 2002). TLR4 is also critical for mediating the proinflammatory signaling and gene transcription in response to an IS LPS injection, because induction of most genes evaluated in this study was clearly impaired in the cerebral tissue of $\mathrm{C} 3 \mathrm{H} / \mathrm{HeJ}$ mice.

Although $\mathrm{C} 3 \mathrm{H} / \mathrm{HeJ}$ mice were relatively insensitive to LPS, the endotoxin was still capable of triggering gene expression in the CNS of these mice. However, strong differences were observed in the time of induction and between the different transcripts. For example, TNF- $\alpha$ mRNA levels were strong $24 \mathrm{hr}$ after the IS LPS infusion, but the signal essentially vanished at $72 \mathrm{hr}$ in the brains of these animals whereas it remained high in those of $\mathrm{C} 3 \mathrm{H} / \mathrm{HeN}$ mice. The ability of $\mathrm{C} 3 \mathrm{H} / \mathrm{HeJ}$ mice to exhibit a low, but signifi- 
cant, response to LPS implies that signaling pathways, other than those mediated by TLR4, may take place in the brain. It is indeed possible that high concentrations of LPS within the injection site stimulate low affinity receptors expressed in a subpopulation of microglia/macrophages specifically within the CNS. It is also possible that induction of proinflammatory cytokines by cells lining the cannula track promotes expression of such low-affinity receptors and then increases signaling once the endotoxin cognates to these putative receptors. TLR4- and CD14independent mechanisms have already been proposed for neutrophil recruitment and LPS clearance (Haziot et al., 2001).

In contrast to most genes analyzed here, in situ hybridization failed to detect any positive signal for iNOS in the cerebral tissue of $\mathrm{C} 3 \mathrm{H} / \mathrm{HeJ}$ mice challenged with the endotoxin combined with vehicle or MK-801. The gene encoding iNOS has been identified recently as one of a class of genes dependent of IFN-I $\beta$, which is produced by macrophages in response to different cell wall components (Toshchakov et al., 2002). It is, therefore, possible that other receptors mediate the effects of LPS in the cerebral tissue or endogenous released soluble molecules are responsible to trigger expression of genes, such as iNOS.

In this regard, innate immune response in the CNS is the result of a coordinated expression of cytokines and other inflammatory mediators in response to infection and insults. It remains, however, difficult to analyze the exact consequences of this response during pathological conditions. There is now compelling evidence of a bilateral talk between glia and neurons, and molecules involved in such interaction may play key roles in neurodegenerative processes. Glutamate is a putative mediator, because it is a major excitatory neurotransmitter and its metabolism and synaptic concentrations are regulated by astrocytes. Various glutamate receptor subtypes are expressed in astrocytes, oligodendrocytes, as well as in microglia (Noda et al., 2000; Bezzi and Volterra, 2001; Matute et al., 2001). Even more attractive is the fact that glutamatergic neurotoxicity has been implicated in many neurodegenerative diseases, especially at the level of NMDA receptor subtype, and molecules acting through NMDA are released by immune-stimulated macrophages and during neuroinflammatory diseases (Piani et al., 1992; Bezzi et al., 2001; Kaul et al., 2001).

The coadministration of LPS and noncompetitive antagonist MK-801 increased the expression levels of TLR2 mRNA and other inflammatory genes, which supports the concept that glutamatergic pathways can modulate immune reaction in the brain. It is interesting to note that MK-801 did not exacerbate the effects of LPS on all the genes assayed here, and the role of glutamate cannot be generalized to all the transcriptional processes that take place in response to an intracerebral bolus of LPS. However, the genes that were significantly modulated by the antagonist of the NMDARs were clearly dependent on the previous binding of LPS
$I_{\kappa} \mathrm{B} \alpha \mathrm{mRNA}$

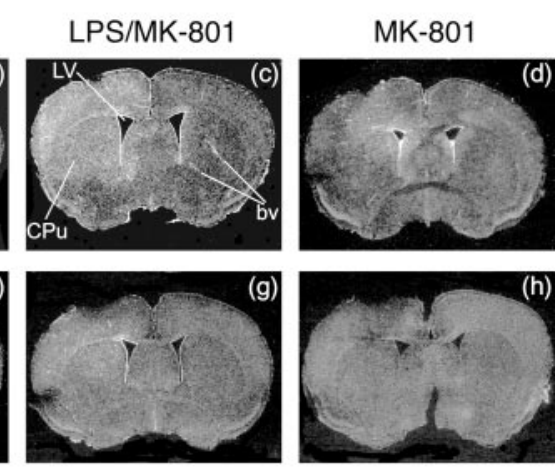

iNOS mRNA
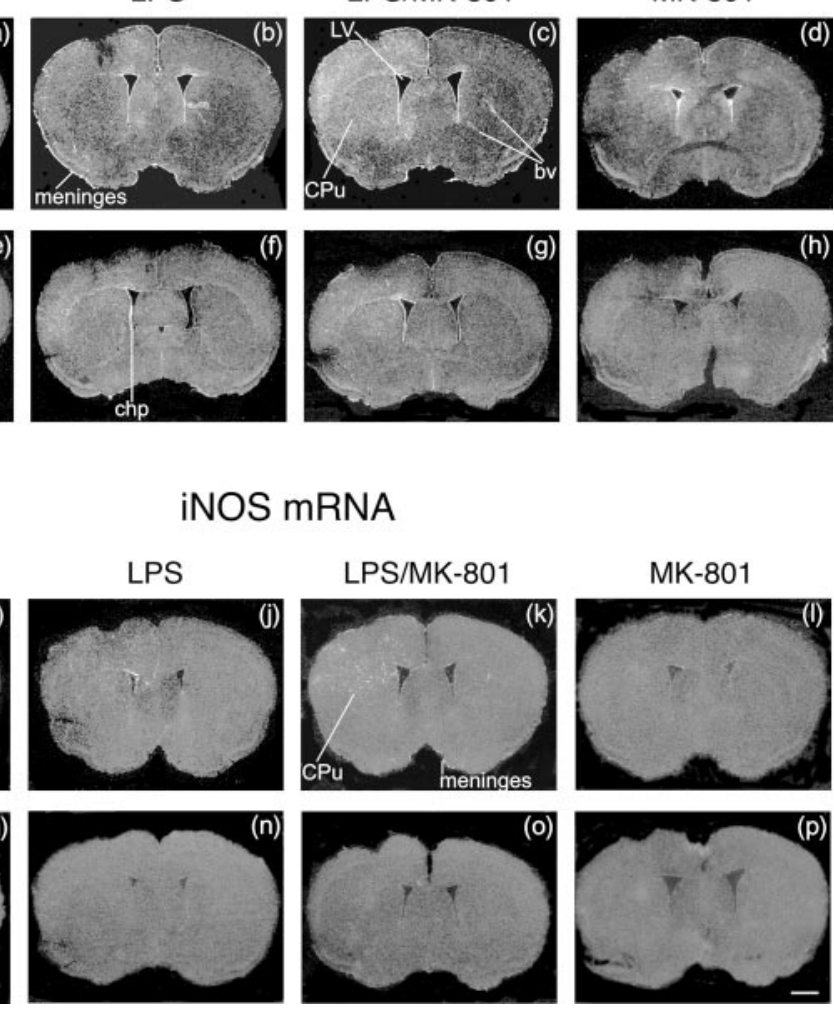

a and iNOS gene expression $A$, Dark-field photomicrographs taken from coronal sections hybridized with radioactive $I_{\kappa} B \alpha c R N A$ probe and dipped into nuclear emulsion milk. These images are representative examples of the expression pattern of $\mid \kappa B \alpha$ transcript (used here as an index of NF- $\kappa B$ activity) $(a-h) 6 \mathrm{hr}$ after the infusion with saline, LPS, LPS plus MK-801, or MK-801 alone. B, Positive signals for iNOS mRNA were only detected in C3H/HeN to show any positive signal for the mRNA encoding iNOS. bv, Blood vessels; cc, corpus callosum; chp, choroid plexus; CPu, caudate putamen; LV, lateral ventricle. Scale bar, $1000 \mu \mathrm{m}$.

to its receptor TLR4. Although the impaired response to the endotoxin in $\mathrm{C} 3 \mathrm{H} / \mathrm{HeJ}$ mice may explain the failure of $\mathrm{MK}-801$ to modulate the effects of LPS, inflammation is still induced in the brain of these animals. The ability of MK-801 to exacerbate the immune response to LPS should, therefore, be detectable with such mild microglial reactivity. However, this was not the case, and the interaction between the endotoxin and NMDARs was observed only in $\mathrm{C} 3 \mathrm{H} / \mathrm{HeN}$ mice, which indicates that TLR4 plays a critical role in this process. It is also possible that MK-801 acts only in presence of a robust immune reaction, such as in LPS-treated $\mathrm{C} 3 \mathrm{H} / \mathrm{HeN}$ mice. This led us to propose that a full response to LPS, which is TLR4 dependent, could be essential for the ability of NMDARs to modulate proinflammatory signaling and gene transcription.

MK-801 has been found recently to be toxic for microglial cells in culture, which underscores the existence of NMDARs in these cells (Hirayama and Kuriyama, 2001). Inhibition of NMDARs also has the ability to increase IFN- $\gamma$-induced expression of major histocompatiblity complex class II in microglia in vivo (McCluskey and Lampson, 2001). Taken together, these data indicate that NMDARs are novel players in the control of the innate immune system in the presence of cell wall components derived from Gram-negative bacteria.

Despite the robust inflammatory response and changes in the signal intensity by MK-801, no signs of neurodegeneration were 
A
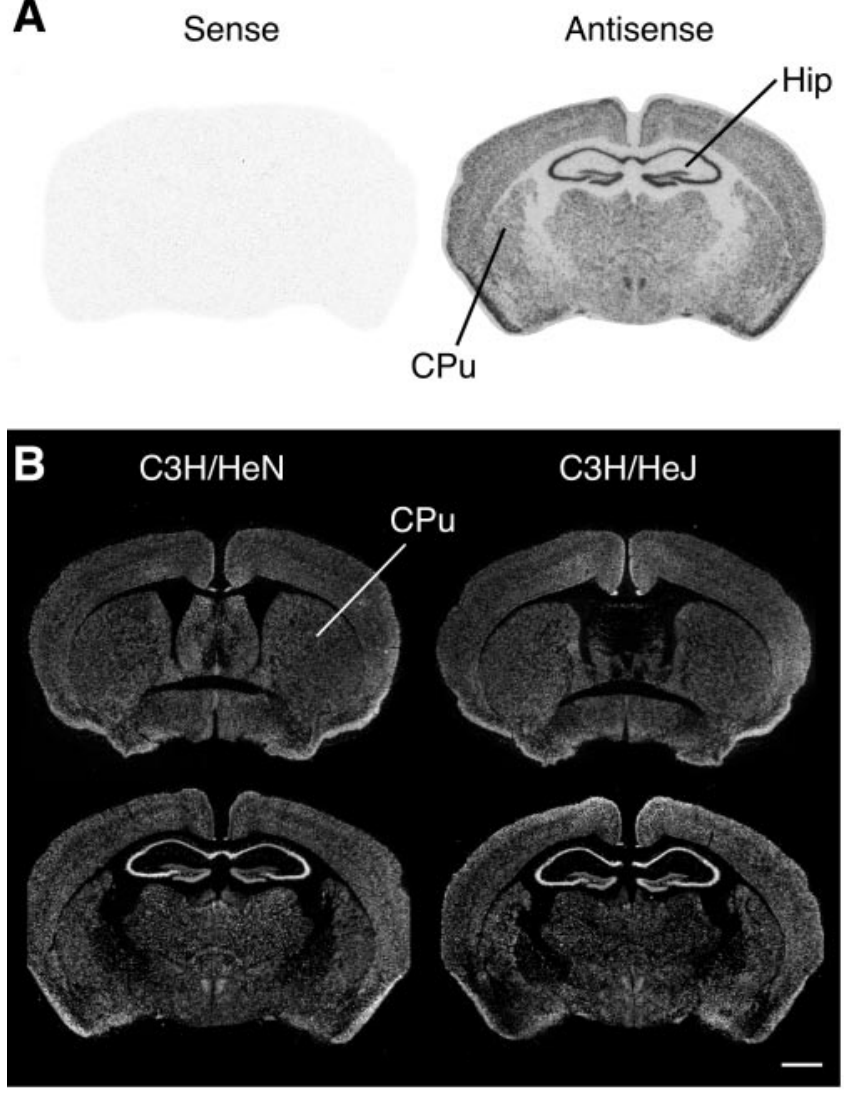

C

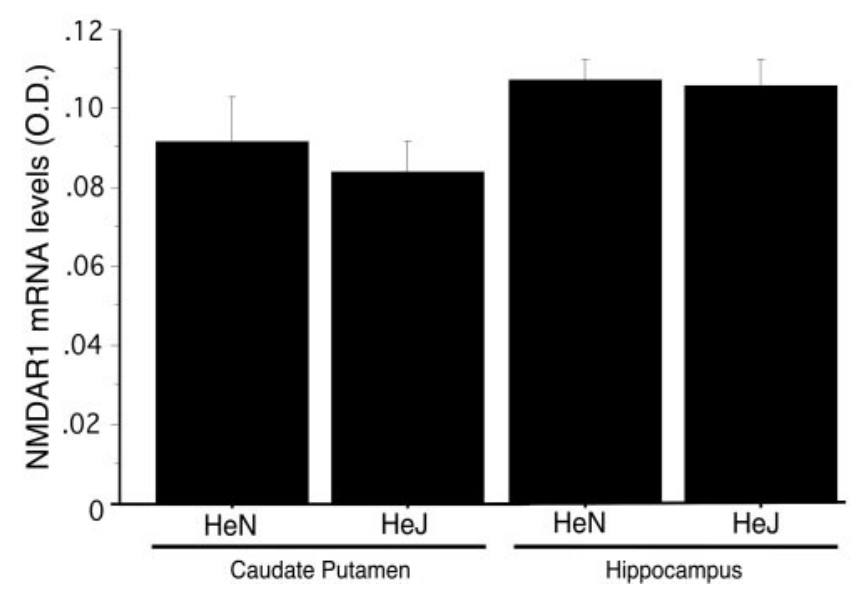

Figure 5. Expression of NMDAR1 subunit $m R N A$ in the brain of $\mathrm{C} 3 \mathrm{H} / \mathrm{HeN}$ and $\mathrm{C} 3 \mathrm{H} / \mathrm{HeJ}$ mice. $A$, Representative signals in coronal sections hybridized with sense or antisense riboprobe and exposed to $x$-ray films (Biomax; Kodak). B, Dark-field photomicrographs taken from coronal sections hybridized with radioactive NMDAR1 CRNA probe and dipped into nuclear emulsion milk. Intensity and pattern of the hybridization signal were similar across the brains of $\mathrm{C} 3 \mathrm{H} / \mathrm{HeN}$ and $\mathrm{C} 3 \mathrm{H} / \mathrm{HeJ}$ mice. C, Semiquantitative analysis of relative NMDAR1 mRNA levels (OD) in the caudate putamen (CPu) and hippocampus (Hip) of $\mathrm{C} 3 \mathrm{H} / \mathrm{HeN}$ and $\mathrm{C} 3 \mathrm{H} / \mathrm{HeJ}$ mice. Scale bar, $1000 \mu \mathrm{m}$.

observed via FJB and Nissl stain techniques. This was also the case in the brain of $\mathrm{C} 3 \mathrm{H} / \mathrm{HeJ}$ mice that exhibited impairment of the immune reaction after IS infusions with the different solutions. Although TLR2 mRNA signal was still positive 2 weeks after LPS infusion in $\mathrm{C} 3 \mathrm{H} / \mathrm{HeN}$ mice, the brain of these animals failed to show any signs of altered neuronal morphology and neurodegeneration. This is further supported by the negative signal for the

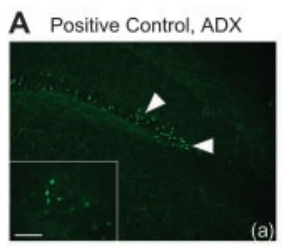

HeN LPS/MK-801 24h

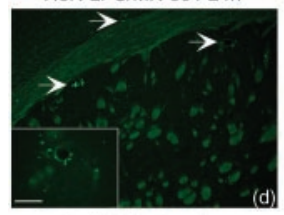

HeN LPS 2 weeks

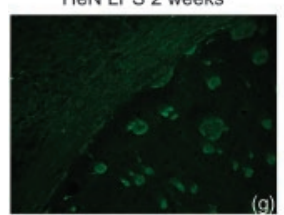

B

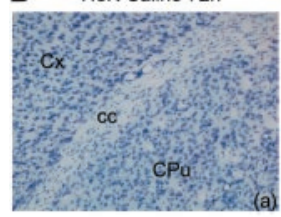

HeN LPS 2 weeks ipsi

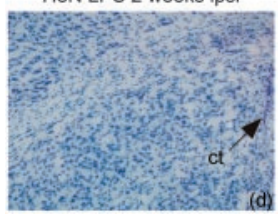

HeN Saline 24h

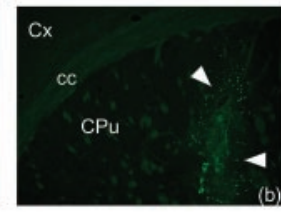

HeN LPS $72 h$

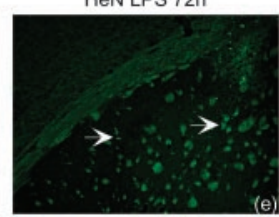

HeJ LPS 24h

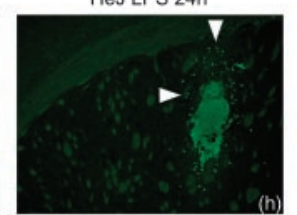

HeN LPS 72h

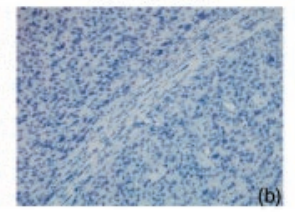

HeN LPS 2 weeks contra

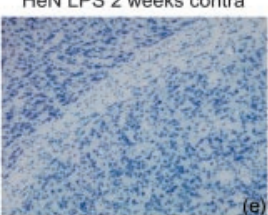

HeN LPS 24h

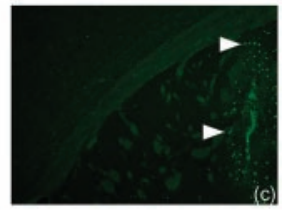

HeN LPS/MK-801 72h

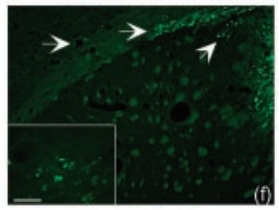

HeJ LPS $72 \mathrm{~h}$

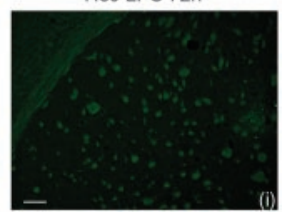

HeN LPS/MK-801 72h

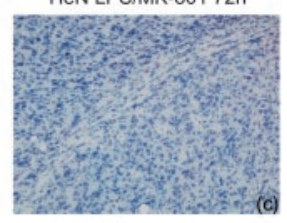

HeJ LPS 2 weeks ipsi

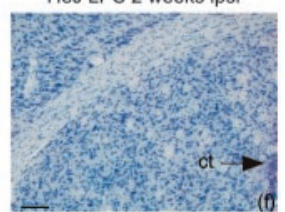

Figure 6. Neuronal integrity in the brain of $\mathrm{C} 3 \mathrm{H} / \mathrm{HeN}$ and $\mathrm{C} 3 \mathrm{H} / \mathrm{HeJ}$ mice after intrastriatal infusion of LPS and the antagonist of NMDARs. $A$, The fluorochrome FJB was used as a marker for histochemical localization of degenerative neurons. Degenerating neurons (positive control) were found in hippocampus of a rat killed $6 \mathrm{~d}$ after being adrenalectomized ( $a$, inset). Such positive neurons were never observed in regions depicting the robust expression of the different transcripts, except along the needle track because of the mechanical injury (white arrowheads). Small non-neuronal cells (probably infiltrating cells) were also found in the CNS of $\mathrm{C} 3 \mathrm{H} / \mathrm{HeN}$ mice treated with LPS alone or combined with MK-801 (white arrows). B, Nissl-stained sections at the level of dorsal basal ganglia. Neuronal density and morphology were similar among all the groups included in this study. Black arrows point to the cannula track. Cx, Cortex; cc, corpus callosum; contra, contralateral side; $\mathrm{CPu}$, caudate putamen; ipsi, ipsilateral side; ct, cannula track. Scale bars, $100 \mu \mathrm{m}$; insets, $50 \mu \mathrm{m}$.

cytokine IFN- $\gamma$ and IL-12, which could be associated with an adaptive immune response linked to a chronic inflammatory process. The physiological relevance of the long-term expression of TLR2 in response to a single bolus of LPS still remains to be clarified.

In disagreement with this study and others (Szczepanik et al., 1996; Nadeau and Rivest, 2002) are the reports that provided evidence of LPS-induced neurotoxicity (Castano et al., 1998; Kim et al., 2000). Different techniques used for assaying neurodegeneration and regional neuronal susceptibility or regional density of microglial cells may explain the discrepancies between the studies. In the present case, microglial activation was robust and, because of the lack of convincing signs of neurodegeneration, we propose that acute innate immune response is not detrimental for the cerebral tissue. In contrast, uncontrolled immune response can have profound detrimental consequences for the cerebral elements (Nadeau and Rivest, 2003; Soulet and Rivest, 2003). Our results demonstrate that long-term infusion of LPS 
HeN TLR2

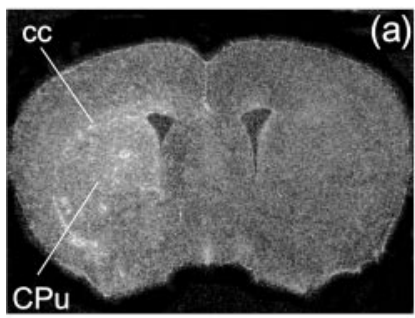

$\mathrm{HeN} / \kappa \mathrm{B} \alpha$

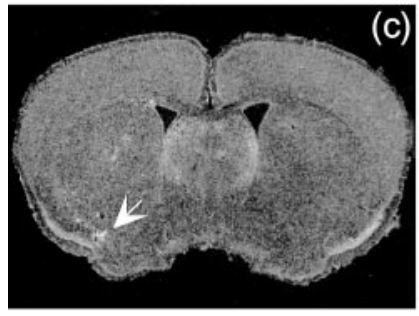

HeN IL-12
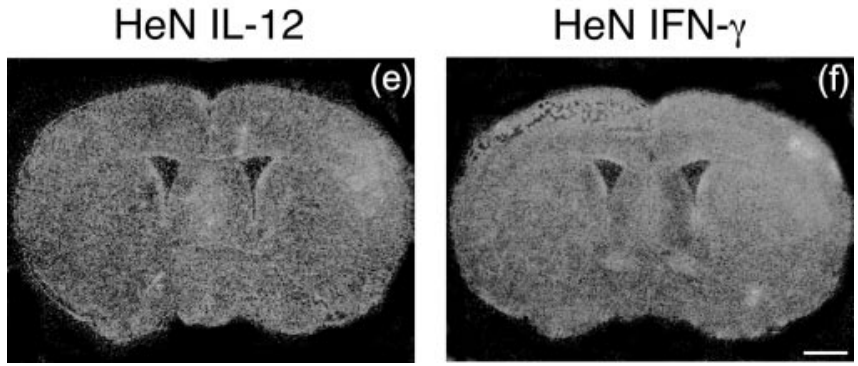

Figure 7. The innate immune response is not associated with a transfer to the adaptive immunity. Representative examples of nuclear emulsion-dipped coronal sections depicting expression of genes involved in the transfer from the innate to adaptive immune response 2 weeks after LPS injection in the dorsal striatum. TLR2 mRNA was still expressed in the ipsilateral side of $\mathrm{C} 3 \mathrm{H} / \mathrm{HeN}$ mice $14 \mathrm{~d}$ after a single bolus of LPS $(a)$, whereas such signal was not present in the infused regions of $\mathrm{C} 3 \mathrm{H} / \mathrm{HeJ}$ mice $(b)$. Few $\mathrm{I}_{\kappa \mathrm{B}} \alpha$ - and TNF- $\alpha$-expressing cells were also found in the brain of $\mathrm{C} 3 \mathrm{H} / \mathrm{HeN}$ mice $(c, d$, white arrows). In situ hybridization failed to detect any positive signal for IL-12 and IFN- $\gamma$ across the cerebral tissue of $\mathrm{C} 3 \mathrm{H} / \mathrm{HeN}$ mice ( $e$ and $f$, respectively). cc, Corpus callosum; (Pu, caudate putamen. Scale bar, $1000 \mu \mathrm{m}$.

combined with an NMDAR antagonist is able to provoke demyelination, which is a critical component in neurodegenerative diseases such as Alzheimer's disease (de la Monte, 1989; Roher et al., 2002; Pak et al., 2003). These data, together with the fact that glutamate unbalance takes place in MS (Werner et al., 2001), indicate that deregulation of the immune response by NMDARs may have a determinant role in brain disorders, especially in demyelinating diseases.

In conclusion, TLR4 is crucial for MK-801 to modulate the innate immune reaction in response to intraparenchymal LPS bolus. The robust and transient inflammatory wave induced by the bacterial cell wall component and NMDAR antagonist was not associated with cell death in the CNS. In contrast, long-term exposure to the same treatment provokes demyelination. There is, therefore, a fine line between beneficial and detrimental properties of immune-related compounds in the brain, and NMDARs may play a determinant role in this equilibrium.

\section{References}

Akira S, Takeda K, Kaisho T (2001) Toll-like receptors: critical proteins linking innate and acquired immunity. Nat Immunol 2:675-680.

\section{A}
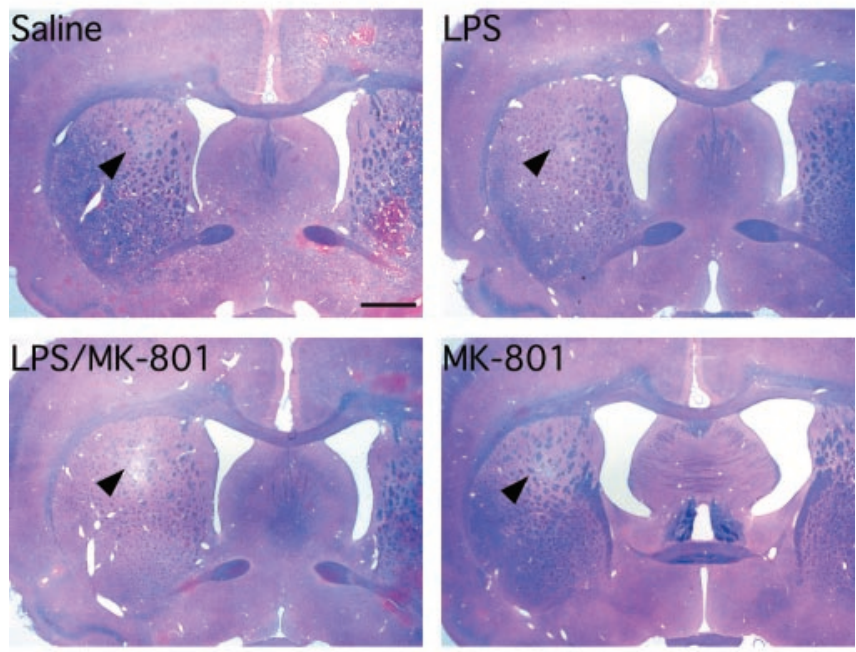

B

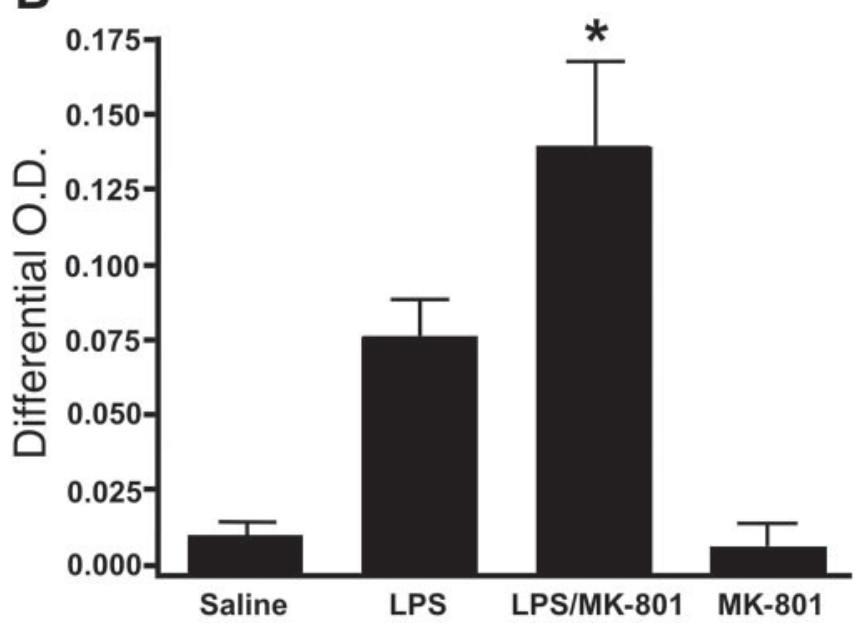

Figure 8. Demyelination in response to long-term infusion of the endotoxin LPS and NMDAR antagonist MK-801 in ipsilateral sides of adult male SD rats. A, Luxol Fast Blue-stained coronal sections from animals infused with saline, LPS $(0.5 \mu \mathrm{g} / \mathrm{d})$, LPS combined with MK-801 (1 $\mu \mathrm{g} / \mathrm{d}$ ), or MK-801 alone and killed $72 \mathrm{hr}$ after implantation of mini-osmotic pumps. $B$, Differential OD measured in several rostrocaudal sections of each rat included in this experiment. Statistical analysis was performed by using a one-way ANOVA, followed by a Bonferroni's multiple comparison test. ${ }^{*}$ Significantly different $(p<0.01$ ) from the saline-injected group. For more details on image analysis, see Materials and Methods. Black arrowheads indicate the tip of the cannula. Scale bar, $1250 \mu \mathrm{m}$.

Anderson KV (2000) Toll signaling pathways in the innate immune response. Curr Opin Immunol 12:13-19.

Beal MF (1995) Aging, energy, and oxidative stress in neurodegenerative diseases. Ann Neurol 38:357-366.

Beutler B (2000) Tlr4: central component of the sole mammalian LPS sensor. Curr Opin Immunol 12:20-26.

Bezzi P, Volterra A (2001) A neuron-glia signalling network in the active brain. Curr Opin Neurobiol 11:387-394.

Bezzi P, Domercq M, Brambilla L, Galli R, Schols D, De Clercq E, Vescovi A, Bagetta G, Kollias G, Meldolesi J, Volterra A (2001) CXCR4-activated astrocyte glutamate release via TNF $\alpha$ : amplication by microglia triggers neurotoxicity. Nat Neurosci 4:702-710.

Boivin G, Coulombe Z, Rivest S (2002) Intranasal herpes simplex virus type 2 inoculation causes a profound thymidine kinase dependent cerebral inflammatory response in the mouse hindbrain. Eur J Neurosci 16:29-43.

Castano A, Herrera AJ, Cano J, Machado A (1998) Lipopolysaccharide intranigral injection induces inflammatory reaction and damage in nigrostriatal dopaminergic system. J Neurochem 70:1584-1592. 
de la Monte SM (1989) Quantitation of cerebral atrophy in preclinical and end-stage Alzheimer's disease. Ann Neurol 25:450-459.

Ghosh S, May MJ, Kopp EB (1998) NF- $\kappa$ B and rel proteins: evolutionary conserved mediators of immune responses. Annu Rev Immunol 16:225-260.

Gonzales-Scarano F, Baltuch G (1999) Microglia as mediators of inflammatory and degenerative diseases. Annu Rev Neurosci 22:219-240.

Haziot A, Hijiya N, Gangloff SC, Silver J, Goyert SM (2001) Induction of a novel mechanism of accelerated bacterial clearance by lipopolysaccharide in CD14-deficient and Toll-like receptor 4-deficient mice. J Immunol 166:1075-1078.

Heese K, Fiebich BL, Bauer J, Otten U (1998) NF-kappaB modulates lipopolysaccharide-induced microglial nerve growth factor expression. Glia 22:401-407.

Herx LM, Rivest S, Yong VW (2000) Central nervous system-initiated inflammation and neurotrophism in trauma: IL-1 beta is required for the production of ciliary neurotrophic factor. J Immunol 165:2232-2239.

Hirayama M, Kuriyama M (2001) MK-801 is cytotoxic to microglia in vitro and its cytotoxicity is attenuated by glutamate, other excitotoxic agents and atropine. Possible presence of glutamate receptor and muscarinic receptor on microglia. Brain Res 897:204-206.

Kaul M, Garden GA, Lipton SA (2001) Pathways to neuronal injury and apoptosis in HIV-associated dementia. Nat Neurosci 410:988-994.

Kim WG, Mohney RP, Wilson B, Jeohn GH, Liu B, Hong JS (2000) Regional difference in susceptibility to lipopolysaccharide-induced neurotoxicity in the rat brain: role of microglia. J Neurosci 20:6309-6316.

Laflamme N, Rivest S (2001) Toll-like receptor 4: the missing link of the cerebral innate immune response triggered by circulating gram-negative bacterial cell wall components. FASEB J 15:155-163.

Laflamme N, Lacroix S, Rivest S (1999) An essential role of interleukin1beta in mediating NF-kappaB activity and COX-2 transcription in cells of the blood-brain barrier in response to a systemic and localized inflammation but not during endotoxemia. J Neurosci 19:10923-10930.

Laurie DJ, Seeburg PH (1994) Regional and developmental heterogeneity in splicing of the rat brain NMDAR1 mRNA. J Neurosci 14:3180-3194.

Matute C, Alberdi E, Domercq M, Perez-Cerda F, Perez-Samartin A, Sanchez-Gomez M (2001) The link between excitotoxic oligodendroglial death and demyelinating diseases. Trends Neurosci 24:224-230.

McCluskey LP, Lampson LA (2001) Local immune regulation in the central nervous system by substance $P$ vs. glutamate. J Neuroimmunol 116:136-146.

Nadeau S, Rivest S (2002) Endotoxemia prevents the cerebral inflammatory wave induced by intraparenchymal lipopolysaccharide injection: role of glucocorticoids and CD14. J Immunol 169:3370-3381.

Nadeau S, Rivest S (2003) Glucocorticoids play a fundamental role in protecting the brain during innate immune response. J Neurosci 23:5536-5544.

Nguyen MD, Julien JP, Rivest S (2002) Innate immunity: the missing link in neuroprotection and neurodegeneration? Nat Rev Neurosci 3:216-227.

Noda M, Nakanishi H, Akaike N (1999) Glutamate release from microglia via glutamate transporter is enhanced by amyloid-beta peptide. Neuroscience 92:1465-1474.

Noda M, Nakanishi H, Nabekura J, Akaike N (2000) AMPA-kainate sub- types of glutamate receptor in rat cerebral microglia. J Neurosci 20:251-258.

Pak K, Chan SL, Mattson MP (2003) Presenilin-1 mutation sensitizes oligodendrocytes to glutamate and amyloid toxicities, and exacerbates white matter damage and memory impairment in mice. Neuromol Med 3:53-64.

Pasinetti G (1998) Cyclooxygenase and inflammation in Alzheimer's disease: experimental approaches and clinical interventions. J Neurosci Res 54:1-6.

Paxinos G, Franklin KBJ (2001) The mouse brain in stereotaxic coordinates, Ed 2. San Diego: Academic.

Paxinos G, Watson C (1998) The rat brain in stereotaxic coordinates, Ed 2. San Diego: Academic.

Piani D, Spranger M, Frei K, Schaggner A, Fontana A (1992) Macrophageinduced cytotoxicity of N-methyl-D-aspartate receptor positive neurons involves excitatory amino acids rather than oxygen intermediates and cytokines. Eur J Immunol 22:2429-2436.

Poltorak A, He X, Smirnova I, Liu MY, Van Huffel C, Du X, Birdwell D, Alejos E, Silva M, Galanos C, Freudenberg M, Ricciardi-Castagnoli P, Layton B, Beutler B (1998) Defective LPS signaling in C3H/HeJ and C57BL/ 10ScCr mice: mutations in Tlr4 gene. Science 282:2085-2088.

Roher AE, Weiss N, Kokjohn TA, Kuo YM, Kalback W, Anthony J, Watson D, Luehrs DC, Sue L, Walker D, Emmerling M, Goux W, Beach T (2002) Increased A beta peptides and reduced cholesterol and myelin proteins characterize white matter degeneration in Alzheimer's disease. Biochemistry 41:11080-11090.

Schipke CG, Ohlemeyer C, Matyash M, Nolte C, Kettenmann H, Kirchhoff F (2001) Astrocytes of the mouse neocortex express functional N-methylD-aspartate receptors. FASEB J 15:1270-1272.

Schmued LC, Albertson C, Slikker Jr W (1997) Fluoro-Jade: a novel fluorochrome for the sensitive and reliable histochemical localization of neuronal degeneration. Brain Res 751:37-46.

Simonian NA, Coyle JT (1996) A oxidative stress in neurodegenerative diseases. Annu Rev Pharmacol Toxicol 36:83-106.

Soulet D, Rivest S (2003) Polyamines play a critical role in the control of the innate immune response in the mouse central nervous system. J Cell Biol 162:257-268.

Stoll G, Jander S (1999) The role of microglia and macrophages in the pathophysiology of the CNS. Prog Neurobiol 58:233-247.

Szczepanik AM, Fishkin RJ, Rush DK, Wilmot CA (1996) Effects of chronic intrahippocampal infusion of lipolysaccharide in the rat. Neuroscience 70:57-65.

Toshchakov V, Jones BW, Perera PY, Thomas K, Cody MJ, Zhang S, Williams BR, Major J, Hamilton TA, Fenton MJ, Vogel SN (2002) TLR4, but not TLR2, mediates IFN-beta-induced STAT1alpha/beta-dependent gene expression in macrophages. Nat Immunol 3:392-398.

Underhill D, Ozinsky A (2002) Toll-like receptors: key mediators of microbe detection. Curr Opin Immunol 14:103-110.

Wallin RP, Lundqvist A, More SH, Bonin A, Kiessling R, Ljunggren HG (2002) Heat-shock proteins as activators of the innate immune system. Trends Immunol 23:130-135.

Werner P, Pitt D, Raine CS (2001) Multiple sclerosis: altered glutamate homeostasis in lesions correlates with oligodendrocyte and axonal damage. Ann Neurol 50:169-180. 